\title{
Creating meaningful partnerships to increase Indigenous student confidence and motivation towards university: The Stellar Program
}

\begin{tabular}{c|c}
$\begin{array}{c}\text { Troy Irwin } \\
\text { Southern Cross University, Lismore } \\
\text { troy.irwin@scu.edu.au }\end{array}$ & $\begin{array}{c}\text { Rachel Callahan } \\
\text { Southern Cross University, Lismore } \\
\text { rachel.callahan@scu.edu.au }\end{array}$ \\
Beris Duroux \\
Department of Education and Communities, Grafton \\
beris.duroux@det.nsw.edu.au
\end{tabular}

Keywords: Clarence Valley, Stellar, university outreach, university participation.

\section{Introduction}

Stellar aims to increase the number of Clarence Valley students participating in university by creating meaningful partnerships between schools, business, government, community organisations and individuals. Stellar is able to create these partnerships because it is driven by the Clarence Valley Industry Education Forum (Forum) which is strongly connected to the community. Forum members are largely passionate Clarence Valley residents who provide direction, resources, and community links. Southern Cross University (SCU) and University of New England (UNE) jointly implement Stellar whilst the Forum provides input to the strategic direction and contributes to the implementation of activities.

Stellar has formed key relationships with Clarence Valley Indigenous communities facilitated by the Forum's Aboriginal Education Consultative Group (AECG) member who has been instrumental from the beginning in shaping the Stellar operating principles and creating links and support with Indigenous communities.

Stellar partners with both Indigenous and non-Indigenous high school students in the Clarence Valley. The initial design of Stellar was heavily focused around tailoring activities to partner with Indigenous students, families and communities. Stellar has become known as a program that works 'with' Indigenous people and connections have deepened by joint sharing and participation in Indigenous community activities. Stellar facilitates many opportunities both at school and through university visits for Clarence Valley students. They also learn from local role models ranging from current university students who recently graduated from their high school to professionals from local businesses through interactive activities designed to build knowledge of courses and careers and get students thinking that university is a possible option for them. Stellar also provides information and encouragement for teachers, parents and community so they are equipped to support their children to strive for higher education. Community activities are strongly partnered with Indigenous organisations and community members and are flexible so that they meet the needs of the community. Stellar's engagement is early from Year 6 to Year 10 and sustained - at least two direct activities per year per year level in addition to community based activities. 


\section{Community driven vision}

In 2006, the Regional Education Director of the Department of Education and Communities (also a local Clarence Valley resident) was facing an unacceptable situation in the Clarence Valley. Year 12 completion rates were extremely low with only 8.5\% (Clarence Valley Council, 2011) of the Valley's population having attained a university degree, well below the Australian average of $17.0 \%$ (Australian Bureau of Statistics, 2011) and less than $1.4 \%$ of the population attending a university, again below the average for NSW at 4.4\% (Clarence Valley Council, 2011).

In response to this situation, the Director created the Clarence Valley Industry Education Forum'. The purpose of the Forum is to strategically support and build the future of young people in the Clarence Valley and meet industry and community needs through dynamic partnerships in key program areas. Initially the Forum developed and implemented two key programs; CareerLink, which facilitated school-based traineeships and pathways to employment program and FreshStart, an award-winning program that delivered employability programs, work experience activities and work placements for Indigenous students.

The Forum acknowledged that a number of factors, including distance, socio-economic status and school attainment were hampering Clarence Valley student's aspirations for careers requiring higher education qualifications. The Southern Cross University Forum representative, Head of the SCU Equity and Diversity Office, recognised an opportunity to address this need through the Federal Government Higher Education Participation and Partnerships Program (HEPPP) and instigated conversations within the Forum to develop a higher education aspiration building program. The Forum developed a Strategic Plan which formed the basis for a successful HEPPP funding application for a new Forum program, Stellar, which started in April 2013.

\section{Nurturing new ideas}

The nature of community involvement means that Stellar operates inside an environment that embraces new ideas directly related to community needs. Forum members share a joint vision which ensures that Stellar's implementation strategies are characterised by community planning, participation and partnering. Forum members not only provide direction but also time and resources to implement activities. For example, Year 10 role model careers days are held annually at each High School. Students rotate through interactive sessions run by different Forum partners including, Clarence Valley Council, SCU, UNE and TAFE which results in student exposure to a wide variety of role models.

Southern Cross University (SCU) is the lead implementer of Stellar which is funded through the Federal Department of Education Higher Education Participation and Partnerships Program (HEPPP) 2013 Indigenous Round. The Grant requirements are that the funds will not be used for marketing of any individual higher education provider which further enables Stellar to focus on local community needs and circumstances, making it truly student focused. The Head of SCU's Equity and Diversity Office and UNE Academic Registrar negotiated an agreement for joint implementation of Stellar with the Stellar Coordinator located in SCU and a Program Officer located at UNE. This agreement puts Clarence Valley students at the centre of Stellar's goals and objectives.

1. Forum members include Southern Cross University (SCU), University of New England, TAFE NSW - North Coast Institute, NSW Department of Education \& Communities - North Coast Region, Clarence Valley Council, Grafton High School, McAuley Catholic College, South Grafton High School, Maclean High School, Induna School, Aboriginal Education Consultative Group, Community representative, Commonwealth Department of Prime Minister and Cabinet - Indigenous Affairs Group. 


\section{Support among Indigenous communities}

Indigenous people make up a large, and growing, proportion of the Clarence Valley population. $30.9 \%$ of the Clarence Indigenous population is aged between 5 and 17 years, compared to $17.0 \%$ for non-Indigenous Valley residents (Clarence Valley Council, 2011). In the past, Clarence Valley Indigenous community members, including elders and parents, had very limited opportunities to participate in higher education. Children often did not see that there were any career possibilities for them in the local area. These communities wanted more for their children and grandchildren because they know that education is one of the keys to a successful future. They wanted their children and grandchildren to have careers, not just a job. They saw the Stellar initiatives as one of the ways to help their children achieve this.

Stellar's strong connection with Clarence Valley Indigenous communities is an important factor enabling Stellar to create meaningful partnerships to encourage student confidence and motivation towards university. One of the most influential and founding members of the Forum was representing the Aboriginal Education Consultative Group (AECG). This person is highly respected within Clarence Valley Indigenous communities. From the beginning, the AECG representative had an equal say and contribution to how Stellar looked and operated. The AECG representative would then make the contact with community members keeping them all involved. These organisations and people would in turn consult with their contacts and provide feedback to the AECG representative to input to Forum meetings and Stellar activities. From the early stages of the Stellar Program, the AECG Representative was very active in influencing the design and structure so that Stellar actively consulted and partnered with community organisations rather than coming with preconceived plans and activities. This enabled Stellar to connect with the communities in a way that was welcomed and accepted.

The AECG Representative nurtured Stellar's relationships with Indigenous Community Organisations by arranging Stellar team members to attend Interagency and other key meetings. This facilitation enabled community members and organisations to openly express their needs so that Stellar was better able to find opportunities for connection and joint activities. As the AECG member often explained, "we don't care how much you know until you show us how much you care". This has been one of Stellar's underlying values. The broader Indigenous community was encouraged and enthusiastic and supported the Stellar activities. Stellar was discussed in very positive ways at Indigenous Interagency meetings.

The AECG member believed that informal networks are the most effective method of spreading information in Clarence Valley Indigenous communities - relationships are the key. Sharing events and working together, works best. Stellar staff spent time developing relationships, attending events and meetings and slowly became better known and accepted as a program that works 'with' Indigenous communities. Sponsorship of a local Indigenous junior Rugby League team to attend the Knockout football carnival was particularly effective at forming trusting relationships. Stellar contributed towards purchase of jerseys and partnered with the parents to run a fund raising barbeque. The parents raised money and at the same time Stellar promoted 'University is Possible' messages to parents and children. Following this sponsorship, two other senior community members became strong advocates of Stellar and mobilised their community connections to encourage Stellar's "University Is Possible For You" message. This informal advocacy has led to broad knowledge ${ }^{2}$ of Stellar as a Program and that Stellar is all about "getting our kids into Uni".

The Forum recognised that change in student knowledge, attitudes and aspirations can be more effectively influenced by a broad number of people including parents, Elders, peers, university mentors and Stellar staff. To better organise the wide-ranging messages to students the Forum, through SCU, engaged staff experienced in community development 
and passionate about Indigenous futures. The skills and attitudes of Stellar Program staff also contributed to the strength of partnerships with Clarence Valley Indigenous communities. One Stellar Program Officer is Indigenous and is passionate about young people's futures and the Stellar Program Coordinator has a community development background with experience partnering with Indigenous communities. Stellar's activities are grounded in research of similar successful programs. Activities start early in schooling, are sustained for five years and link with key influencers.

\section{Theoretical Basis}

In addition to the practical consultative design process undertaken through the Forum, Stellar also has a strong theoretical basis. The program is designed to follow Stewart's (2010) strategies for a successful aspiration-raising program and aligns with aligns with Gale's (2010) people rich program design methodology (Fig. 1).

Figure 1. Theoretical base

\section{Stewart (2010)}

\begin{tabular}{l|l|l|l}
$\begin{array}{l}\text { Progressive set of interventions } \\
\text { targeted at the whole cohort and } \\
\text { starting early and sustained over } \\
\text { time. }\end{array}$ & $\begin{array}{l}\text { Focus upon raising } \\
\text { aspiration and } \\
\text { also improving } \\
\text { attainment. }\end{array}$ & $\begin{array}{l}\text { Collaborative } \\
\text { partnerships } \\
\text { with all key } \\
\text { stakeholders, } \\
\text { including other } \\
\text { universities. }\end{array}$ & $\begin{array}{l}\text { Interventions } \\
\text { designed to raise } \\
\text { aspirations. }\end{array}$ \\
& $\begin{array}{l}\text { Engage schools, } \\
\text { families and } \\
\text { stakeholders in the } \\
\text { wider community. }\end{array}$ &
\end{tabular}

\section{Gale (2010)}

Assembling Resources - peoplerich; financial support; early, long-term, sustained; cohort based.

\begin{tabular}{l|l} 
Engaging learners & Working together \\
- recognise & - collaboration. \\
difference; & \\
enhanced & \\
academic & \\
curriculum; & \\
research-driven. &
\end{tabular}

Building

Confidence familiarisation; communication and information.

The Stellar Program

Early - start in Year 6.

Long Term - Year 6 to Year 10 (with continuing academic support to Year 12.

Sustained - 1 to 3 interventions each year for five years.

People-rich - exposes students to many different people with different higher education and career journeys.

Cohort based - The majority of Stellar activities engage with the whole year level in four schools across the Clarence Valley.
Stellar undertakes aspiration building activities for each year level and also provides an afterhours online tutoring service for Years 9-12.
Stellar partners with Forum members including local high schools, local council and TAFE to implement a variety of activities for parents and students.
Stellar activities are designed to build student and parent confidence and motivation towards higher education and provide knowledge about university courses and careers. 
The community nature of Stellar ensures that a variety of people contribute to Stellar activities. It also means that program implementation relies on contributions from many people. For example, in the Year 10 Stellar Role Model Careers days, students have conversations with current SCU and UNE students and staff, Clarence Valley Council and TAFE North Coast professional staff. This provides students with exposure to many different people's experiences, skills and knowledge. It also enables Stellar activities to be tailored to the specific needs of each community and school. Another example is the parent evening that follows the Year 9 Unlock Your Passion - a school based event designed to facilitate students to recognise their passions and create a road map to follow those passions. In the evening following this event, Stellar partners with the high school and the parent committee to hold a parent information evening. This was instigated by the school who noticed an increase of enquiries and discussion with the parent committee about the Year 9 student event.

By age 15 individual students have largely made up their mind about their potential for university and are driving their own aspiration (Gemici \& Lu, 2014). Therefore it is important to ensure actions taken to expose young people to new ideas or experiences occur at a younger age and well before Years 9 and 10 (National Centre for Vocational Education Research, 2015). Successful programs engage with students early in their schooling and expose students to regular messages over a long-term (Gale, 2010).

Stellar responds to this by engaging with students starting in Year 6 with two activities designed to introduce them to the language of university, some of the careers which require university education and university as a place that is friendly, welcoming and enjoyable. In Year 7, students participate in a one-day workshop in which they design their 'Recipe For Success' to succeed in high school and position them for the possibility of university at the end of year 12. Personal attitude messages include choosing the right attitude, supporting friends for success, and having courage. University messages include debunking university myths, experiences of current university students about their high school challenges, and how they overcame these challenges.

"It is not often Ethan comes home willing to discuss his day's events at school but last Wednesday we could not keep him quiet. He excitedly told us all the activities he got up to, then proceeded to tell us that now he is undecided as to whether he will be a civil engineer or a robotic engineer. It is great the kids can be exposed to all these different career paths, many of which parents would never dream of" (Parent Feedback, 2014).

In Year 8, students visit a different university campus and explore the different university courses through a fun and interactive program of activities across the university. When students reach Year 9 they start broadening their interests and increasingly explore new ideas and concepts. So during this year Stellar facilitates a day long workshop supporting students to 'Unlock Your Passion'. During the day's activities they hear from role models who share their experience in finding their passion, unlocking opportunities and having the courage to chase their passions. Also in Year 9, students experience first-hand university life through a two-days/one-night immersion at another university campus. Students live in university student accommodation, participate in fun and interactive lectures and activities designed to give them the complete 'uni experience'. Year 10 students participate in a role model careers day in which they hear from local people who have experienced university study and are working in their chosen field. Teachers report students making positive changes as a result of Stellar activities: 
"We believe the program has had a big impact on the students who have taken part. They are more of aware of University, what it is, how it works and what it looks like than they were before. It has become a point of discussion for some students and their families. The students now regard Stellar as part of their education and look forward to the next events. Many of the students have become familiar with you and your staff and probably regard you guys as mentors. A lot of the students seem to be thinking more about careers" (Deputy Principal Feedback, 2014).

"Those [students] who might have not considered it [university], now would like to go. [Stellar] allows all students no matter what background to have the opportunity to consider going to university" (Teacher Feedback, 2014).

One of the most important indicators of success in both accessing higher education and in succeeding in university is prior academic achievement (Stewart, 2010). In recognition of this, Stellar provides students from Year 9 to 12 access to an online after hours tutorial service. This is a digital variation of an after-school homework centre, offering students one-to-one, ondemand help with homework and study across core curricula: English, writing skills, literacy, maths at all high school levels, biology, chemistry, physics, general science, as well as other core subjects. The online, just-in-time, no appointments help offers guidance from expert teachers, to improve students' confidence as well as their thinking and enquiry skills. After using the service $82 \%$ of Stellar students felt more confident with their schoolwork: "All of my questions were answered clearly and I feel much more confident with writing a history essay now :-)" (Student feedback following a tutorial 2015).

\section{Engaging with parents and community}

Parents and siblings play a significant role in shaping the aspirations of young people, especially in Years 5, 6, 7 and 8 (Wilks, 2010). Students whose parents want them to attend university are four times more likely to complete Year 12 (Gemici, Bednarz, Karmel, \& Lim, 2014). Many parents express a desire for their children to progress to university but concerns about barriers such as finances, academic performance and leaving home can reduce their aspirations (Wilks, 2010). Conversely:

"Parents with high expectations for their children can compensate for a lack of financial and human resources by demonstrating more optimistic expectations for their children, which can serve to increase children's own expectations, and eventual school attainment" (Yu \& Daraganova, 2014).

In recognition of this Stellar seeks to provide information to parents so they are better equipped to nurture their child's aspirations and passions. Stellar undertakes various activities such as parent evenings at local schools, community centres and the local library. Parent evenings include presentations from local Clarence Valley current university students and their parents, as well as local support agencies such as Centrelink. Stellar's community and family activities further sustain these aspiration building messages by maintaining visibility at community events such as sporting family days, sports sponsorships, cinema evenings, and parenting festivals. 


\section{Going where the people are}

During the design phase of Stellar, the Forum's AECG Representative ensured that one of the fundamental operating principles was to 'go where the people are'. This recognises that many parents, carers and community members are often too busy to attend school functions and going to a school can be seen as an unpleasant experience (Alford \& James, 2007). Often some families only attend school when their child is subject to disciplinary action and therefore over a long period of time have a conflict-based relationship with school. In order to 'go where the people are', Stellar partners with community organisations, attends community family fun days, sponsors community sporting teams and carnivals. This means that Stellar can engage with community in a way that schools cannot and can therefore provide information when parents are open to hearing it.

An example that demonstrates the benefits of Stellar partnerships is the Stellar Cinema Under the Stars event. For this event Stellar partnered with three local organisations, a local Indigenous healthy lifestyles program, a group of community parents who were raising funds to send a local rugby league junior football team and Clarence Valley Council. Each group contributed to the event according to their capability and resources. For example, the Council funded laser skirmish game for kids, the health promotion organisation provided the outdoor cinema screen, and the community group provided food for the evening. Each organisation promoted the event through their networks to encourage attendance. The community benefitted by enjoying a fun evening and at the same time they received messages about the education and health. Community feedback was very positive: "We really could not have done this without Stellar's support. It meant so much to the boys to attend the games, and the Stellar sponsorship was a genuine way of helping the community come together for this important cultural event." (Indigenous Rugby League Team Manager, 2014)

During Indigenous community family fun days and sporting carnivals, Stellar sets up a marquee with university information, a photo booth and small competitions which have drawn people to the marquee. Indigenous parents and other Indigenous community members are the target group for this activity. Stellar runs competitions for small prizes such as footballs and netballs. To enter the competition people answer three questions about how to get in to university. These questions are designed to stimulate discussion about the costs and pathways to university which are common concerns of students and parents. These days have been very well attended with several hundred people at each event. Stellar staff report many good conversations around the possibility of attending university with parents and students.

Successful university outreach programs recognise that not all students and communities are the same (Gale, 2010). Stellar responds to this by ensuring that activities best respond to local student's needs. Stellar also has Indigenous only activities such as an overnight university experience which brings Clarence Valley Indigenous students to a university campus and responds to local Indigenous needs and concerns. Through fun activities students receive information about different university courses and support mechanisms that provide a sense of belonging, are culturally safe, and facilitate contact with family and community.

\section{Program evaluation}

Stellar engages with students early in their schooling (Year 6), exposing them to consistent messages over the long term (five years) which are two components of a successful widening participation program (Gale, 2010). The first cohort of students that have participated in the Stellar Program will complete Year 12 in 2017. 
In the initial planning of Stellar, the Forum undertook an initial measurement of baseline data through student surveys and focus groups collecting data on attitudes towards university, desire to attend university, confidence in reaching university, perceived barriers to reaching university and knowledge of university courses, pathways, and what it's like at university. Baseline data showed that only $53 \%$ of 260 Year 7 students expressed a desire to go to university. Only $25 \%$ believed they could reach university and $63 \%$ believed they had some chance. The main barriers that these students perceived were financial, high school grades, and having to leave family and friends. $48 \%$ believed the best thing about university would be to be able to study what they were interested in (Stellar Program, 2013).

Since the program's implementation an evaluation framework has utilised surveys, feedback forms and 'experience' stories from students, teachers and parents participating in different aspects of the program. Results of student surveys have been outstanding and points towards a positive change in attitude about the possibility and motivation towards university. For example, $84 \%$ of Year 10 students who recently participated in the Stellar Role Model Careers day indicated that they were more confident about being able to attend university and $86 \%$ indicated that they were more interested in going to university after attending the day. Students report positive changes in attitude: "I had a friend who didn't want to go to university but then they came here and now they do." (South Grafton High School Student Feedback, 2014)

Fifty parents were surveyed following a 2014 Parent Evening at Maclean High School in which current university students and parents of current university students talked about their experiences getting to university. $70 \%$ of respondents had not been to university. Parents reported that having simple specific information about pathways, costs and real examples of how people cope with these finances improved their confidence that their child could reach university. $96 \%$ of these parents reported being more interested in university for their child and $100 \%$ were more confident that university was a very real possibility for their child (Stellar Program, 2014).

Indigenous parents and community members have provided some very positive feedback about their children. Indigenous Elders in Maclean have said that Stellar has given their kids an opportunity to find out about university and what it offers, some children are the first in their family to be aiming to complete Year 12 and through Stellar they can see a 'light at the end of the tunnel'. By taking up options provided through Stellar such as the online tutorial service and university visits, they have goals and feel as though they have options at the end of year $12 .^{3}$

Stellar Project evaluations received ethics clearance through SCU's ethics process. This enabled data to be collected from students and parents for enable reporting and evaluation of program activities. Due to the young age of many of the students - ensured that mechanisms were in place to minimise undue emotional discomfort and ensure procedures were in place in case a student experienced discomfort. 
Table 1: Sample of evaluation results and comments

\begin{tabular}{|c|c|c|}
\hline Year 6 & $\begin{array}{l}\text { After attending the } 2014 \text { Campus visit: } \\
\text { - } 81 \% \text { of students were more } \\
\text { confident of getting to uni. } \\
\text { - } 86 \% \text { know more about the different } \\
\text { ways to get to uni. }\end{array}$ & $\begin{array}{l}\text { "I think differently about uni now } \\
\text { because I didn't know that you can } \\
\text { [study] whenever you want." } \\
\text { Year } 6 \text { student feedback following } 2014 \\
\text { Campus visit. }\end{array}$ \\
\hline Year 7 & $\begin{array}{l}\text { After attending the } 2015 \text { Recipe for } \\
\text { Success activity at High Schools: } \\
\text { - } 74 \% \text { ranked 'being able to study } \\
\text { what I'm interested in' } \\
\text { as the best thing about going to uni } \\
\text { - } 85 \% \text { are more confident that they } \\
\text { can reach uni. }\end{array}$ & $\begin{array}{l}\text { "I try harder in all my subjects to try } \\
\text { to get my grades up so I have a really } \\
\text { strong chance of getting into university, } \\
\text { which is a big dream of mine since the } \\
\text { stellar visit" } \\
\text { Year } 7 \text { student feedback following the } \\
2014 \text { Recipe for Success school event. }\end{array}$ \\
\hline Year 8 & $\begin{array}{l}\text { After attending the } 2015 \text { Year } 8 \text { Great } \\
\text { Race at SCU Lismore Campus: } \\
\text { - } 90 \% \text { are more interested in going to } \\
\text { university } \\
\text { - } 79 \% \text { intend to talk to their parents } \\
\text { about going to uni. }\end{array}$ & $\begin{array}{l}\text { "The Stellar Program has really helped } \\
\text { me think about my future" } \\
\text { Year } 8 \text { student feedback following } \\
\text { the } 2014 \text { Great Race at SCU Lismore } \\
\text { campus. }\end{array}$ \\
\hline Year 9 & $\begin{array}{l}\text { After participating in the } 2014 \text { Year } 9 \\
\text { UNE Uni Experience at UNE Armidale } \\
\text { campus: } \\
\text { - } 95 \% \text { are more confident that they } \\
\text { can reach university } \\
\text { - } 91 \% \text { are more interested in going to } \\
\text { university } \\
\text { - } 90 \% \text { rank 'being able to study what } \\
\text { I'm interested in' as the best thing } \\
\text { about going to uni. }\end{array}$ & $\begin{array}{l}\text { "I had a friend who didn't want to go to } \\
\text { university but then they came here and } \\
\text { now they do." } \\
\text { Year } 9 \text { student feedback following the } \\
\text { UNE Uni Experience. }\end{array}$ \\
\hline Year 10 & $\begin{array}{l}\text { After attending the Year } 10 \text { Role Model } \\
\text { Careers day at their schools: } \\
\text { - } 80 \% \text { are more interested in going to } \\
\text { university } \\
\text { - } 80 \% \text { are more confident that they } \\
\text { can reach uni } \\
\text { - } 75 \% \text { intend to talk to their parents } \\
\text { about going to uni. }\end{array}$ & $\begin{array}{l}\text { "I thought the program was a great } \\
\text { success and influenced a number of } \\
\text { students from MCC" } \\
\text { Year } 10 \text { student feedback following the } \\
2014 \text { Role Model Careers Day at high } \\
\text { schools. }\end{array}$ \\
\hline Years 9-12 & $\begin{array}{l}\text { After participating in an online tutorial } \\
\text { session in } 2015 \text { : } \\
\text { - } 89 \% \text { of students feel more } \\
\text { confident with schoolwork after an } \\
\text { online tutorial session. }\end{array}$ & $\begin{array}{l}\text { "All of my questions were answered } \\
\text { clearly and I feel much more confidant } \\
\text { with writing a history essay now" } \\
\text { Student feedback following a tutorial } \\
\text { session in } 2015 \text {. }\end{array}$ \\
\hline
\end{tabular}




\section{Conclusion}

The Clarence Valley Stellar Program has created meaningful partnerships to encourage knowledge, confidence and motivation towards university. A key to Stellar's success is that it has been created by a widely representative group of like-minded community organisations and people passionate about creating genuine, respectful connections and partnerships with Indigenous organisations and individuals. Meaningful partnerships are created with students, teachers and community members by operating with underlying principles of 'going where the people are' and 'genuine respect'. Stellar provides opportunities for students to hear many different perspectives and learn from role models within their own community through many different activities and initiatives. Stellar's programs are people-rich, long-term, sustained and support academic attainment. In the past many Clarence Valley students often didn't see that there was anything in the future for them. Through the Forum and the Stellar Program, many students are much more positive about a possible future that includes a satisfying and rewarding career, not just a job, and are setting their personal goals to include higher education as a way to achieve their dreams.

\section{References:}

Aboriginal Rugby League Team Manager. (2014). Stellar sponsorship of the Bulgarr Ngaru Junneguns Rugby League Team.

Alford, K., \& James, R. (2007). Pathways and barriers: Indigenous schooling and vocational education and training participation in the Goulburn Valley region. Adelaide, Australia: NCVER.

Australian Bureau of Statistics. (2011). Census (people over 15 years old). Retrieved from http:// www.abs.gov.au/ausstats/abs@.nsf/Lookup/by\%20Subject/1301.0 2012 Main\%20 Features Educational\%20attainment 110.

Clarence Valley Council. (2011). Clarence Community Profile 2011. Retrieved from http://profile.id.com. $\mathrm{au} /$ clarence-valley/qualifications .

Clarence Valley Council. (2011). Community Profile - Indigenous Age Structure. Retrieved from http:// profile.id.com.au/clarence-valley/indigenous-age-structure?BMID=40.

Cuthbert, C., \& Hatch, R. (2009). Educational aspiration and attainment amongst young people in deprived communities. Edinburgh, UK: Centre for Research on Families and Relationships.

Gale, T. (2010). Interventions early in school as a means to improve higher education outcomes for disadvantages (particularly low SES) students. Canberra, Australia: Australian Department of Education, Employment and Workplace Relations.

Gemici, S., \& Lu, T. (2014). Do schools influence students engagement in the high school years? Adelaide, Australia: NCVER.

Gemici, S., Bednarz, A., Karmel, T., \& Lim, P. (2014). The factors affecting the education and occupational aspirations of youn Australians. Adelaide, Australia: National Centre for Vocational Education Research.

National Centre for Vocational Education Research. (2015, April 14). Young people are significantly impacted by their educational and career 'inheritance'. Insight Issue \#54. Retrieved from http:// www.ncver.edu.au/.

Stewart, A. (2010). Widening Participation? Yes we can! Insights from policy and leading practice in three countries; England Ireland and USA. Brisbane, Australia: University of Queensland.

Wilks, J. (2010). Challenging the Odds: Access and Participation in University for Students from Low Socio-Economic Backgrounds: Final Report. Lismore, Australia: Southern Cross University .

Yu, M., \& Daraganova, G. (2014). The educational expectations of Australian children and their mothers. In A. I. Studies (Ed.), Longitudinal Study of Australian Children Annual Statistical Report 2014 (pp. 105-129). Canberra, Australia: Commonwealth of Australia. 